
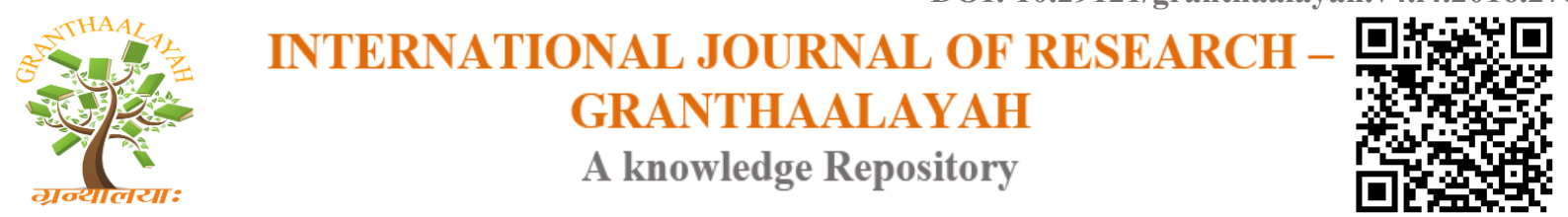

Science

\title{
EFFECT OF LEAVES EXTRACT OF IPOMOEA CAIRICA ON CHLOROPHYLL AND CAROTENOID IN PARTHENIUM HYSTEROPHOROUS L.
}

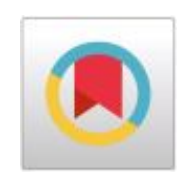

\author{
Deepa Srivastava ${ }^{* 1}$, K.Shukla ${ }^{2}$ \\ ${ }^{* 1,2}$ Department of Botany, D.D.U Gorakhpur University, Gorakhpur, Uttar Pradesh, INDIA
}

\begin{abstract}
Photosynthetic effects of the leaves extracts from Ipomoea cairica on Parthenium hysterophorus $L$ were studied. Ipomoea cairica dried leaf powder (20g) was dissolved in distilled water $(200 \mathrm{ml})$ for foliar application. The seedlings were maintained under natural condition in Insect free net house. The experiment was carried out to analyze the effects of Ipomoea cairica leaves extract by measuring chlorophyll 'a', chlorophyll 'b', total chlorophyll and carotenoid contents in Parthenium. The experimental plants were sprayed 20 days after emergence and control plants were maintained by a simultaneous spray of distilled water. Leaves of Parthenium hysterophorus were collected at 5 days interval following the foliar application of Ipomoea cairica leaves extract up to 15th day. Results showed that Chlorophyll (total chlorophyll, chlorophyll $a$ and $b$ ) and carotenoid content was adversely affected as the duration of Ipomoea cairica leaves extract increased. This potential of Ipomoea cairica can be used as herbicide to control noxious weed Parthenium hysterophorous.
\end{abstract}

Keywords:

Ipomoea cairica, Parthenium hysterophorous, chlorophyll a, chlorophyll b, carotenoids, total chlorophyll.

Cite This Article: Deepa Srivastava, and K.Shukla, "EFFECT OF LEAVES EXTRACT OF IPOMOEA CAIRICA ON CHLOROPHYLL AND CAROTENOID IN PARTHENIUM HYSTEROPHOROUS L." International Journal of Research - Granthaalayah, Vol. 4, No. 4 (2016): 103-107.

\section{INTRODUCTION}

Weeds are among the main components of the agro-ecosystem that interfere in crop production [1]. They compete for resources, reducing production, and can deposit a high quantity of seeds in the soil, perpetuating the problem during future plantings [2]. Excessive use of synthetic herbicides can cause pollution of soil and water [3] Natural compounds have some advantages over synthetic compounds, such as absence of halogen molecules and a shorter half-life [4]. Natural products, allelochemicals and plant extracts cannot provide the same level of weed control when compared to synthetic herbicides, but they can be worthwhile when only a small 
quantity of herbicide can be used [5]. Parthenium hysterophorous is a noxious weed found throughout India. Ipomoea cairica leaves extract has been found to affect adversely against the growth of Parthenium hysterophorous due to decrease in chlorophyll content and enzyme activity [6]. This property of Ipomoea cairica can be used as natural herbicide to control Parthenium hysterophorous.

Ipomoea cairica is a perennial species of the Convolvulaceae that is widely distributed in tropical regions $[7,8]$. The chemical nature of its secondary metabolites has been examined and two compounds, 3-3'-5-Trihidroxi-4'-7-dimethoxyflanove and 3-3'-5-Trihidroxi-4'-7dimethoxyflavone-3-O-sulphate, were identified as being responsible for its allelopathic properties on radish (Raphanus sativus L.), cucumber (Cucumis sativus L.), Chinese cabbage (Brassica pekinensis) and a weed Ligularia virgaurea, making it a possible candidate for the development of new herbicides based on natural products[8,9]. The aim of this study was to evaluate the activity of aqueous leaf extracts of Ipomoea cairica, on the chlorophyll and carotenoids of Parthenium hysteroporous L.

\section{MATERIAL AND METHODS}

Pot culture experiment was conducted with freshly young seedlings of Parthenium hysterophorus L (Congress Grass). This species are common and dominant in the fields in the surrounding area of Gorakhpur. Administratively the study area $\left(\sim 10,000 \mathrm{~km}^{2} ; 27^{\circ} 05^{\prime}\right.$ to $27^{\circ} 40^{\prime}$ $\mathrm{N}$ latitudes and $83^{\circ} 30^{\prime}$ to $84^{\circ} \mathrm{E}$ longitudes) falls in Gorakhpur district of UP state. It is bounded by Nepal in the north and Bihar state of India in the east. The weed seeds were collected from the University campus. Seeds were soaked in the seed pan for 2 days to obtain maximum germination percentage. After 20 days, the plantlets were sown in the experimental pots containing soil supplemented with farmyard manure in the ratio of 1:3. The seedlings were maintained under natural condition

\section{EXTRACT PREPARATION}

Fresh leaves of Ipomoea cairica were collected from D.D.U Gorakhpur University campus, Gorakhpur. Leaves were washed properly with water and shade dried for 15 days. After drying the leaves was powdered using a mechanical grinder and were stored in air tight containers at $10^{\circ} \mathrm{C}$ for further studies. Aqueous extracts of Ipomoea cairica were prepared as $20 \mathrm{~g}$ of leaves were soaked in $200 \mathrm{~mL}$ distilled water $(10 \%)$, and kept at room temperature of $28-30^{\circ} \mathrm{C}$. After $24 \mathrm{~h}$ the aqueous extracts were filtered through four layered cheese cloth and stored at $6{ }^{\circ} \mathrm{C}$ and tested their effects on pigment content of Parthinum hysterophosus. In the present study only 2022 days old seedlings of Parthenium hysterophorus were treated with Ipomoea cairica leaves extract. The control plants were maintained by a simultaneous spray of distilled water. Pot culture experiments were conducted in the Department of Botany, D.D.U. Gorakhpur University, Gorakhpur, U.P, India.

\section{SAMPLING}

Leaves of Parthenium hysterophorus were collected at 5days interval following the foliar application of Ipomoea cairica upto $15^{\text {th }}$ day. The leaves were thoroughly washed first with tap 
water followed by distilled water and were dried with filter paper. Fresh leaf material was used for the determination of chlorophyll and carotenoids. The chlorophyll content was estimated according to the method of [10], Total carotenoids were determined as per the method of Jensen and Jensen [11]. Data were expressed as Mean \pm Standard deviation of mean (SD).

\section{RESULT AND DISCUSSION}

The objective of present work was to study the effect of Ipomoea cairica leaves extract on chlorophyll fractions like chlorophyll ' $a$ ', chlorophyll ' $b$ ', total chlorophyll and carotenoid on leaves of Parthenium hysterophorus. The results of this study showed that, the control plants chlorophyll content was more in Parthenium hysterophorus, but the Ipomoea cairica leaves extract treatment caused decrease in all the plants up to $15^{\text {th }}$ day over the control respectively in the Parthenium hysterophorous. Thus, the chlorophyll 'a'content is decreased significantly in the treated Parthenium hysterophorus $(0.362,0.239,0.204,0.172)$ (Tab.1, Fig 1). The treated plants showed that the gradual decrease in chlorophyll 'b' content in all the stages of experimental days. The maximum decrease was noticed in the weed plants on $15^{\text {th }}$ day. The decreased levels chlorophyll-b was observed in Parthenium hysterophorus $(0.223 ; 0.185 ; 0.143 ; 0.126)$ on $5^{\text {th }}$, $10^{\text {th }}$ and $15^{\text {th }}$ day respectively over the control (Tab.2, fig 1). The results revealed that the total chlorophyll content was continuously decreased up to $15^{\text {th }}$ day in Parthenium hysterophorus over the control. The reduction in chlorophyll a, chlorophyll $b$ and total chlorophyll contents in 15 days treated leaves is nearly $50 \%$ over control in both the cases. However, the weed species showed consistent decrease at all the experimental days. The result was similarly compared with several reporters work on effect of herbicide [12]( Peter J.Ralph,2000) The content of total carotenoid was also reduced with effect of Ipomoea cairica leaves extract caused gradual decreased carotenoid content in the weed species up to $15^{\text {th }}$ day. The maximum declined was noticed on $15^{\text {th }}$ day only. The decreasing level of carotenoid content in Parthenium hysterophorus $(0.745,0.471,0.316,0.127)$ (Tab.4, Fig 1) when compare to control.

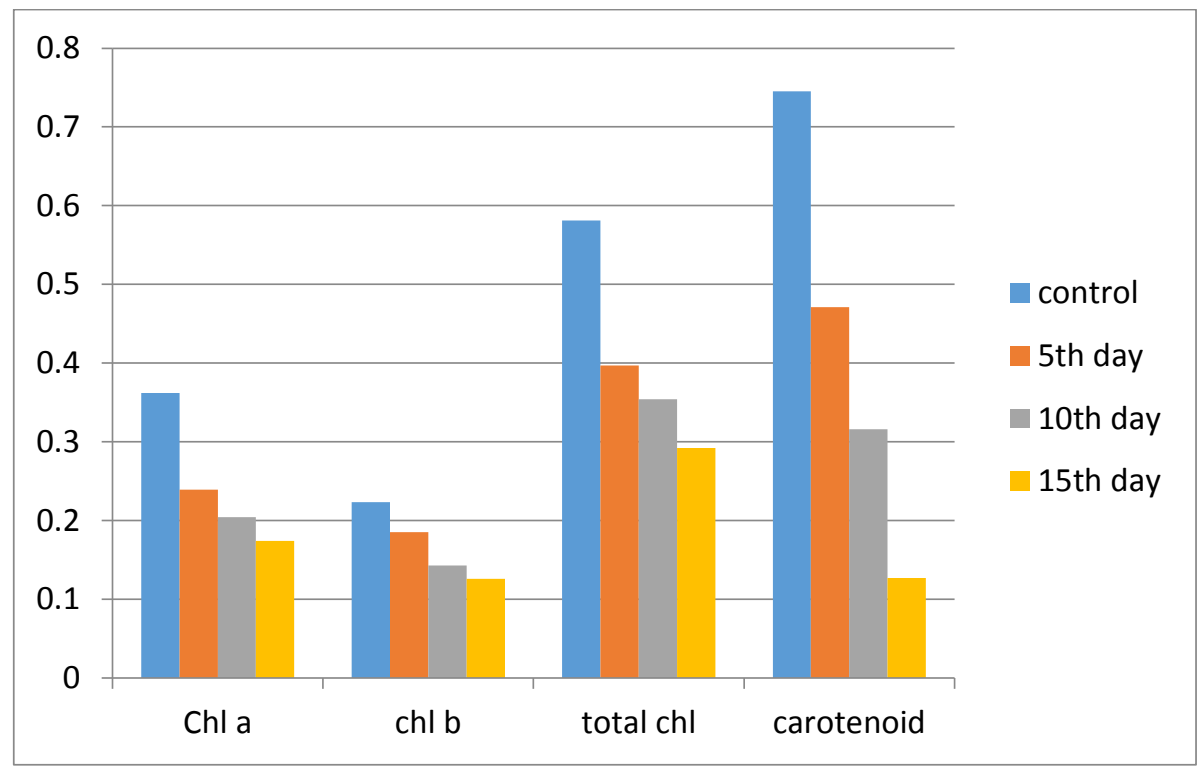

Figure 1: Effect of Ipomoea cairica leaf extract on chl "a", chl "b", total chlorophyll and carotenoid content of Parthenium hysterophorous 
Table 1: Effect of Ipomoea cairica leaves extract on chlorophyll 'a'content on Pa rthenium hysterophorous (mg/g.fwt)

\begin{tabular}{|l|l|l|l|l|}
\hline $\begin{array}{l}\text { Name of the } \\
\text { weed species }\end{array}$ & Days after treatment \\
\hline & Control & $5^{\text {th }}$ day & $10^{\text {th }}$ day & $15^{\text {th }}$ day \\
\hline $\begin{array}{l}\text { Parthenium } \\
\text { hysterophorus } \\
\text { L. }\end{array}$ & $.0 .362 \pm 0.032$ & $0.239 \pm 0.028$ & $0.204 \pm 0.034$ & $0.172 \pm 0.021$ \\
\hline
\end{tabular}

\pm SD Values are mean of 5 replications

Table 2: Effect of Ipomoea cairica leaves extract on chlorophyll 'b' content on weed species (mg/g.fwt)

\begin{tabular}{|l|l|l|l|l|}
\hline $\begin{array}{l}\text { Name of the } \\
\text { weed species }\end{array}$ & Days after treatment \\
\hline & Control & $5^{\text {th }}$ day & $10^{\text {th }}$ day & $15^{\text {th }}$ day \\
\hline $\begin{array}{l}\text { Parthenium } \\
\text { hysterophorus } \\
\text { L. }\end{array}$ & $0.223 \pm 0.029$ & $0.185 \pm 0.021$ & $0.143 \pm 0.023$ & $0.126 \pm 0.092$ \\
\hline
\end{tabular}

\pm SD Values are mean of 5 replications

Table 3: Effect of Ipomoea cairica leaves extract on total chlorophyll content on weed species (mg/g.fwt)

\begin{tabular}{|l|l|l|l|l|}
\hline $\begin{array}{l}\text { Name of the } \\
\text { weed species }\end{array}$ & Days after treatment \\
\hline & Control & $5^{\text {th }}$ day & $10^{\text {th }}$ day & $15^{\text {th }}$ day \\
\hline $\begin{array}{l}\text { Parthenium } \\
\text { hysterophorus }\end{array}$ & 0.581 & 0.397 & 0.354 & 0.292 \\
L. & \pm 0.025 & \pm 0.013 & \pm 0.020 & \pm 0.047 \\
\hline
\end{tabular}

\pm SD Values are mean of 5 replications

Table 4: Effect of Ipomoea cairica leaves extract on carotenoid content in weed species (mg/g.fwt)

\begin{tabular}{|l|l|l|l|l|}
\hline $\begin{array}{l}\text { Name of the } \\
\text { weed species }\end{array}$ & Days after treatment \\
\hline & Control & $5^{\text {th }}$ day & $10^{\text {th }}$ day & $15^{\text {th }}$ day \\
\hline $\begin{array}{l}\text { Parthenium } \\
\text { hysterophorus } \\
\text { L. }\end{array}$ & $0.745 \pm 0.094$ & $0.471 \pm 0.147$ & $0.316 \pm 0.084$ & $0.127 \pm 0.0719$ \\
\hline
\end{tabular}

\pm SD Values are mean of 5 replications 


\section{CONCLUSION}

The present study concluded that Ipomoea cairica leaves extract has a strong effect on Parthenium hysterophorus, effects are directly related to changes in the total chlorophyll and carotenoid content. Similarly chlorophyll 'a' and chlorophyll 'b' contents were also decreased significantly in the weed upto $15^{\text {th }}$ day. Carotenoid content was also declined in the weed species might have contributed to the photo oxidation of chlorophylls. The degradation of chlorophyll and carotenoid content in the present study testifies Ipomoea cairica leaf extract action on photosynthetic activity. This property of Ipomoea cairica can be utilized to control the noxious weed Parthenium hysterophorous.

\section{ACKNOWLEDGEMENT}

Dr. Deepa Srivastava is thankful to UGC, New Delhi for awarding post-doctoral fellowship.

\section{REFERENCES}

[1] Kuva, M.A., Ferraudo, A.S.; Pitelli, R.A., Alves, P.L.C.A. \& Salgado, T.P.Weed plant infestation patterns in raw sugarcane agricultural systems. Planta Daninha 26, 2008, 549-557

[2] Vyvyan, J.A. Allelochemicals as leads for new herbicides and agrochemicals. Tetrahedron 58, 2002,1631-1646

[3] Ahn, J.K., Park, H.Y.,Hwang, S.J., Kong, D.S., Chun, S.C., Khan, T.D. \& Chung, I.M. Screening of aquatic plant extracts for herbicidal, fungicidal and insecticidal activity. Allelopathy Journal 21, 2008,361-372

[4] Duke, S.O. Dayan, F.E.; Ramagnani, J.G. \& Rimando, A.M. 2000. Natural products as sources of herbicides: current status and future trends. Weed Research 40: 99-111.

[5] Khanh, T.D., Chung, I.M., Tawata, S. \& Xuan, T.D. Weed supression by Passiflora edulis and its potential allelochemicals. European Weed Research Society 46, 2006 296303.

[6] Srivastava D., Shahi S. and Rai R (2015)Allelopathic effects of Ipomoea cairica (L) on noxious weed Parthenium hysterophorus Linn.International Journal of Current Research in Life Sciences .4( 12) 2015, 489-491.

[7] Llamas, K.A.Tropical Flowering Plants: a guide to identification and cultivation 1. ed. Portland, Timber Press. 2003.

[8] Ma, R.J., Wang, N.L., Zhu, H., Guo, S.J. \& Chen, D.S.Isolation and identification of allelochemicals from invasive plant Ipomoea cairica. Allelopathy Journal 24, 2009, 77 84.

[9] Takao, L.K., Nepomuceno Ribeiro J.P. and Salgueiro Lima M.I. Allelopathic effects of Ipomoea cairica (L.) Sweet on crop weeds Acta Botanica Brasilica 25(4), 2011, 858-864.

[10] Arnon, D.I. Copper enzymes in isolated chloroplasts. Plant Physiol, 24, 1949, 1-15.

[11] Jensen. S.L. and Jensen. A. Quantitative determination of carotenoids in photosynthetic tissue. In: Methods in enzymology. (Sampictro A, H.d.) Acad. Press. Xcw York and London. 1971.

[12] Peter J. Ralph. Herbicide toxicity of Halophila ovalis assessed by chlorophyll a fluorescence. Aquatic Botany 66, 2000, 141-152. 